\title{
Associational Standing for Organizations with Internal Conflicts of Interest
}

\author{
Nathaniel B. Edmonds $†$
}

The judicial theory of associational standing allows an organization to sue on behalf of an injury to one or more of its members. ${ }^{1} \mathrm{Al}$ though this mode of representation provides for greater and more effective access to the courts because of the greater financial resources and expertise of an organization, ${ }^{2}$ associational standing can also create significant difficulties when not all members of the organization support the litigation, thus creating an internal conflict of interest. ${ }^{3} \mathrm{~A}$ frequent example in the case law occurs when a business association attempts to overturn a statute providing contracting advantages to minority-owned businesses. The business association has members who would be hurt by successful litigation (minority-owned businesses) and members who would be helped by successful litigation (non-minority-owned businesses). ${ }^{5}$ Courts split over how to handle an organization that is litigating on behalf of some of its members and to the detriment of others. ${ }^{6}$ Specifically, some courts have found that or-

$\dagger$ A.B. 1995, Princeton University; J.D. Candidate 2002, The University of Chicago.

1 See James Wm. Moore, 15 Moore's Federal Practice $\$ 101.60$ at 101-97 to 101-102.2 (Matthew Bender 3d ed 2001) (discussing the application of the associational standing doctrine).

2 See International Union, United Automobile, Aerospace, and Agricultural Implement Workers of America v Brock, 477 US 274, 289-90 (1986) (noting that associations "can draw upon a pre-existing reservoir of expertise and capital").

3 See, for example, Maryland Highways Contractors Association, Inc v Maryland, $933 \mathrm{~F} 2 \mathrm{~d}$ $1246,1252-53$ (4th $\mathrm{Cir}$ 1991) (denying standing due to conflicts between members who would benefit from successful litigation and members who would be hurt by successful litigation). Courts have denied standing because of internal conflicts of interest in three main types of cases: (1) business associations challenging regulations favoring one segment of the membership, see, for example, Maryland Minority Contractors Association, Inc v Maryland Stadium Authority, $70 \mathrm{~F}$ Supp 2d 580 (D Md 1998); (2) unions challenging awards of contracts or settlement negotiations that aid a subset of the membership, see, for example, National Maritime Union of America, AFL-CIO v Commander, Military Sealift Command, 824 F2d 1228 (DC Cir 1987); and (3) business associations seeking equitable relief in antitrust actions that could harm individual members, see, for example, NCAA v Califano, 622 F2d 1382 (10th Cir 1980). Courts have occasionally examined other conflicts of interest, such as when corporate management seeks to represent the rights of shareholdets or when special-interest organizations seek redress for indirect economic effects. See, for example, Polaroid Corp v Disney, 862 F2d 987, 997-1002 (3d Cir 1988).

4 See, for example, Maryland Highways Contractors, 933 F2d at 1252-53 (denying a contractors' association standing to overturn a statute that provided advantages to minority-owned businesses because not all of the association's members were minority-owned businesses).

5 See, for example, id.

6 See Sea Shore Corp v Sullivan, 158 F3d 51, 56 n 7 (1st Cir 1998) (noting a split in the circuits); Retired Chicago Police Association v City of Chicago, 7 F3d 584, 603-07 (7th Cir 1993) 
ganizations with internal conflicts of interest may have associational standing while others have denied standing under similar circumstances.

In Hunt $v$ Washington State Apple Advertising Commission, the Supreme Court articulated a three-part test to determine whether an organization can assert associational standing on behalf of its members:

[A]n association has standing to bring suit on behalf of its members when: (a) its members would otherwise have standing to sue in their own right; (b) the interests it seeks to protect are germane to the organization's purpose; and (c) neither the claim asserted nor the relief requested requires the participation of individual members in the lawsuit. ${ }^{8}$

Although this test appears simple and forthright, the Supreme Court has never fully explained the reasoning underlying any of the prongs nor applied the test to an organization with an internal conflict of interest.'

Consequently, lower courts have divided not only over how to apply the test, but also over which prong should be the focus of the analysis. ${ }^{10}$ Some lower courts have found that certain types of "profound" conflicts will foreclose standing under the "germaneness prong." Other courts have determined that the "individual participation prong" is the appropriate analytical tool with which to examine whether an internal conflict of interest will prohibit associational standing. ${ }^{12}$ However, among courts favoring Hunt's individual participation prong, some have found that internal conflicts of interest do

("RCPA I") (discussing the circuit split at length).

7432 US 333 (1977).

8 Id at 343.

9 See, for example, Friends of the Earth, Inc $v$ Laidlaw Environmental Services (TOC), Inc, 528 US 167, 181 (2000) (granting associational standing to a citizen organization suing under the Clean Water Act); Arizonans for Official English v Arizona, 520 US 43, 65-66 (1997) (examining associational standing of a group that sponsored a ballot initiative for an article of the state constitution in a case regarding its constitutionality); United Food and Commercial Workers Union Local 751 v Brown Group, Inc, 517 US 544, 546, 552-53, 555-56 (1996) (granting associational standing to union suing an employer for a violation of a law requiring advanced notice of plant shutdown); Brock, 477 US at 282-88 (granting associational standing to a union in a suit challenging the Secretary of Labor's interpretation of an employment statute).

10 See RCPA I, 7 F3d at 600 ("While the Hunt test is well-established in our jurisprudence and enjoys the specific reaffirmation of the Supreme Court ... the application of the various prongs has, to this date, produced a caselaw that does not lend itself to easy distillation.").

11 See, for example, id at 605-07, discussing Maryland Highways Contractors Association, 933 F2d 1246.

12 See, for example, National Maritime Union, 824 F2d at 1231-32 (holding that even internal conflicts do not foreclose standing under the individual participation prong). 
not prohibit associational standing, ${ }^{13}$ while others have found that certain internal conflicts would prohibit standing if the litigation was not properly authorized by the members of the organization.

This Comment attempts to provide guidance in understanding the myriad approaches to associational standing currently followed by federal appellate courts. A simple two-part test can easily categorize and fully explain the apparent chaos among the circuits. The proposed solution requires formalizing the underlying reasoning of the lower courts' analyses. The solution would require, as a first step, heightened scrutiny of organizations with certain types of "profound" conflicts. Then, in an examination under the germaneness prong, a court should reject standing whenever a profound conflict negates the adversity required by the Case or Controversy Clause of Article III of the Constitution. However, a court should grant associational standing if the organization can show that the litigation was adequately authorized by its members because such a showing suffices to demonstrate sufficient adversity. Profound conflicts also may require individual participation, thus violating Hunt's individual participation prong, but courts should seek other mechanisms to preserve dissenting members' rights.

Part I discusses the constitutional origins of the associational standing doctrine. Part II analyzes the various problems and inconsistencies of the approaches and discuss their theoretical underpinnings. Finally, Part III recommends an easy-to-administer solution that formalizes the current lower courts' analyses, emphasizes how to minimize constitutional concerns, and maximizes judicial efficiency.

\section{THE ORIGINS OF THE ASSOCIATIONAL STANDING DOCTRINE}

This Part explores the foundations of the associational standing doctrine. It examines how the constitutional underpinnings of the standing doctrine limit a federal court's power to hear a case. Then it analyzes the case law origins of the associational standing doctrine, paying particular attention to the principles espoused in each Supreme Court opinion.

\section{A. Article III Limits the Power of the Judiciary to Hear Cases}

Article III restricts courts to hearing only cases and controversies. ${ }^{15}$ However, the general phrasing of Article III allows for various

13 See, for example, id at 1231-34.

14 See, for example, Maryland Highways Contractors, 933 F2d at 1252-53 (holding that the individual participation prong was not met when association filed suit because some members would benefit from the litigation but others would suffer).

15 US Const Art III, $\$ 2$, cl 1:

The judicial Power shall extend to all Cases, in Law and Equity, arising under this Constitu- 
interpretations by courts. ${ }^{16}$ The minimal standing requirement of a "case or controversy" has been interpreted to require that parties before the court have a personal stake in the outcome of the litigation."

Traditionally, courts have interpreted the Article III standing doctrine to forbid the assertion of rights of third parties in order to preserve the "concrete adverseness which sharpens the presentation of issues upon which the court so largely depends for illumination of difficult ... questions." ${ }^{18}$ However, with the increasing complexity of litigation, courts have allowed alternate structures through which organizations or representatives may litigate on behalf of others. ${ }^{19}$ An organization may gain standing when it itself suffers a direct injury ${ }^{20}$ or it may sue as the representative of its injured members. ${ }^{21}$ However, the "concrete adverseness" of the parties remains a critical issue in the development of associational standing. ${ }^{22}$

tion, the Laws of the United States, and Treaties made, or which shall be made, under their Authority; ... to Controversies to which the United States shall be a Party;-to Controversies between two or more States; between a State and Citizens of another State; between Citizens of different States;-between Citizens of the same State claiming Lands under Grants of different States, and between a state, or the Citizens thereof, and foreign States, Citizens, or Subjects.

16 See Haitian Refugee Center v Gracey, 809 F2d 794, 798 (DC Cir 1987) ("It should be said at the outset that the law of standing remains uncertain and unsettled in some of its major branches.").

17 See Lujan v Defenders of Wildlife, 504 US 555, 560-61 (1992). In Lujan, the Supreme Court articulated a three-part test that organizes the constitutional requirements for standing: (1) the party must suffer an "injury in fact" which is concrete and particular and actual or imminent, not conjectural or hypothetical; (2) the injury must be traceable to the disputed action; and (3) a favorable decision must be likely to redress the injury. Id.

18 Flast $v$ Cohen, 392 US 83, 99 (1968) (internal quotation marks omitted), quoting Baker $v$ Carr, 369 US 186, 204 (1962).

19 The best-known example is that of class actions as described in Federal Rule of Civil Procedure 23. See FRCP 23 (discussing prerequisites and procedures for filing class actions). For a comparison of the associational standing doctrine to class actions, see International Union, United Automobile, Aerospace, and Agricultural Implement Workers of America v Brock, 477 US 274, 291-92 (1986).

20 See Simon v Eastern Ky Welfare Rights Organization, 426 US 26, 40 (1976) (denying welfare organization standing because it did not allege an injury to itself).

21 See, for example, Hunt, 432 US at 341-43 (granting an advertisers' association standing because it alleged injury to its members). See also Moore, 15 Moore's Federal Practice $\$ 101.60$ at 101-100 (cited in note 1) (noting that the organization does not have to assert a "personal stake" because it can gain standing solely as the representative of its members).

22 The Supreme Court has repeatedly expressed concern over the zealousness of litigants in associational standing doctrine cases. See, for example, United Food and Commercial Workers Union Local 751 v Brown Group, Inc, 517 US 544, 557 (1996) ("[T]he entire doctrine of 'representational standing,' of which the notion of 'associational standing' is only one strand, rests on the premise that in certain circumstances, particular relationships (recognized either by common-law tradition or by statute) are sufficient to rebut the background presumption ... that litigants may not assert the rights of absent third parties.") (citations omitted); Brock, 477 US at 297 (Powell dissenting) ("This Court has repeatedly expressed its reluctance to confer standing on third parties for fear of inadequate representation."). 


\section{B. The Associational Standing Doctrine Allows Organizations to} Assert the Rights of Their Members

The Supreme Court overcame the constitutional concerns regarding third-party standing in a progression of cases in which the Court found that an organization or association was a better party to bring the litigation than were the original injured parties. The requirement of sufficient adversity, which is an important aspect of associational standing highlighted in the case law, will assist in explaining the impact of internal conflicts of interest.

In its early cases, the Supreme Court focused on how organizations could gain standing to protect the rights of their members. $N A A C P$ v Patterson ${ }^{23}$ was one of the first cases in which the Court held that organizations could assert the rights of their members. ${ }^{24}$ In Patterson, the Court found that an organization could be the best party to protect the rights of its members because the association and its members "are in every practical sense identical." In Warth $v$ Seldin, the Court acknowledged that organizations could gain associational standing even in the absence of injury to the organizations themselves. ${ }^{27}$ The Court insisted, however, that in representing their members, organizations must meet the constitutional case-or-controversy requirement for the Court to have the power to hear the case. ${ }^{23}$ The Court held that a plaintiff might assert the rights of a third party if "countervailing considerations" outweigh judicial reluctance to allow one party to assert the claims of another. The Court also examined how the prospective relief would benefit the members of the organization.

\section{US 449 (1958).}

24 Id at $458-60$.

25 Id at 459. The Court granted representational standing to the NAACP when it sought to assert the privacy rights of its members, calling the association "the medium through which its individual members seek to make more effective the expression of their own views." Id.

26422 US 490 (1975).

27 Id at 511, citing National Motor Freight Association v United States, 372 US 246 (1963).

28 Warth, 422 US at 501, citing United States $v$ Students Challenging Regulatory Agency Procedures, 412 US 669 (1973). This reasoning served as the basis for the first prong of the Hunt test. See analysis in text accompanying note 33 .

29 Warth, 422 US at 500-01. Specifically, the Court noted that the issue of standing involves both constitutional case-or-controversy limitations on a federal court's jurisdiction and the court's own circumspection in exercising its jurisdiction. Id at 498. Both of these prudential considerations, the Court asserted, are founded on the "concern about the proper-and properly limited-role of the courts in a democratic society." Id.

30 Id at 515. The Warth court stated:

[W] hether an association has standing to invoke the court's remedial powers on behalf of its members depends in substantial measure on the nature of the relief sought. If in a proper case the association seeks a declaration, injunction, or some other form of prospective relief, it can reasonably be supposed that the remedy, if granted, will inure to the benefit of those members of the association actually injured. 
The Supreme Court articulated the principle of associational standing in Hunt. In this seminal case, an association of apple growers sought to overturn a North Carolina statute that prohibited Washington State grade symbols on apple containers. ${ }^{31}$ The Court found that the association had standing to represent the interests of its applegrowing members and provided a three-prong test for lower courts to apply in identifying organizations that are seeking associational standing."

Although the Supreme Court has never fully developed the contours of any of the prongs, lower courts have considered the prongs' underlying policies. The first, the members' standing prong, ensures that part of the Article III case or controversy requirement is met by requiring members to have suffered an injury in fact. ${ }^{33}$ The second, the germaneness prong, also examines the constitutional sufficiency of the claim, by requiring an association to have a personal stake in the outcome of the suit. This relationship between the organization's and members' interests assures "concrete adverseness" by limiting the type of interest for which the organization may sue. ${ }^{34}$ The third, the individual participation prong, seeks to ensure that the association will be a better representative than individual members would be in pursuing litigation, thus improving judicial efficiency. ${ }^{35}$

In International Union, United Automobile, Aerospace, and Agricultural Implement Workers of America $v$ Brock, the Supreme Court reaffirmed the Hunt three-part test and explained the purpose and policy of associational standing. ${ }^{37}$ The Court determined that associational representation provides tremendous advantages both to a court and to an organization's members: "The only practical judicial policy when people pool their capital, their interests, or their activities

Id at 515. This reasoning eventually developed into Hunt's third prong. See analysis in text accompanying notes $85-101$.

$31 \quad 432$ US at $336-37$.

32 Id at 343-45. See text accompanying note 8.

33 The Hunt Court quoted Warth for the proposition that " [ $t]$ he Association must allege that its members, or any one of them, are suffering immediate or threatened injury as a result of the challenged action of the sort that would make out a justiciable case had the members themselves brought the suit." Hunt, 432 US at 342-43, quoting Warth, 422 US at 511.

34 United Food and Commercial Workers Union Local 751 v Brown Group, Inc, 517 US 544, 555-56 (1996) ("Hunt's second prong ... raises an assurance that the association's litigators will themselves have a stake in the resolution of the dispute, and thus be in a position to serve as the defendant's natural adversary," thus meeting the constitutional requirements for case or controversy.).

35 See Vivian Weston Lathers, Comment, Associational Third-Party Standing and Federal Jurisdiction under Hunt, 64 Iowa L Rev 121, 131-32 (1978) (analyzing the individual participation prong as ensuring that all proper parties are before the court), citing Hunt, 432 US at 344, and Warth, 422 US at $515-16$.

36477 US 274 (1986).

37 Id at 288-90. 
under a name and form that will identify collective interests, often is to permit the association or corporation in a single case to vindicate the interests of all." ${ }^{33}$ The Court drew a distinction between the benefits and requirements of class actions and associational standing. ${ }^{39}$ The Court rejected the defendant's claim that members of an association are served best by the class action provisions, which provide for special guarantees of adequate representation. ${ }^{40}$ Instead, the Court found that associational standing provides special advantages to both courts and litigants. ${ }^{41}$

Organizations can draw upon a preexisting reservoir of expertise and capital lacked by both individual plaintiffs and the ad hoc unions created by class action groups. ${ }^{42}$ The Court stated that "the primary reason people join an organization is often to create an effective vehicle for vindicating interests that they share with others." ${ }^{43}$ Moreover, the special interest and expertise of a preexisting organization provide the court with "that concrete adverseness which sharpens the presentation of issues upon which the court so largely depends for illumination of difficult ... questions." Again, ${ }^{45}$ the Court highlighted the importance of sufficient advocacy in granting an organization representational standing. ${ }^{46}$ Importantly, each association possesses a self-

38 Id at 290 (internal quotation marks omitted), quoting Joint Anti-Fascist Refugee Committee v McGrath, 341 US 123, 187 (1951) (Jackson concurring). See also 477 US at 290 ("[An] association is but the medium through which its individual members seek to make more effective the expression of their views."), quoting Patterson, 357 US at 459. See also National Association of College Bookstores, Inc v Cambridge University Press, 990 F Supp 245, 251-52 (S D NY 1997) (declaring that because "unanimity in organizations with thousands of members is rarely possible," denying representational standing to organizations with internal conflicts of interest "would clearly be inimical to the goals of judicial efficiency: It is precisely in cases where large organizations are present that the greatest benefits are to be reaped by collective adjudication39). Brock, 477 US at 288-90.

40 Id. See also FRCP 23(a)(4) ("Prerequisites to a Clašs Action. One or more members of a class may sue or be sued as representative parties on behalf of all only if ... (4) the representative parties will fairly and adequately protect the interests of the class."). Although some courts have suggested an additional prong to the Hunt test examining adequate representation, most courts have rejected such a proposition. See Donald F. Simone, Note, Associational Standing and Due Process: The Need for an Adequate Representation Scrutiny, 61 BU L Rev 174, 185 \& nn 6265 (1981) (stating that some cases have examined the adequate representation issue, but "the courts in these cases went beyond ... the language of the Hunt opinion"), discussing Associated General Contractors of ND v Otter Tail Power Co, 611 F2d 684,691 (8th Cir 1979), and Local 194, Retail, Wholesale and Department Store Union $v$ Standard Brands, Inc, 540 F2d 864, 867-88 (7th Cir 1976).

41 Brock, 477 US at 289.

42 Id, citing Dale Gronemeier, Comment, From Net to Sword: Organizational Representatives Litigating Their Members' Claims, 1974 U Ill L F 663, 669.

43 Brock, 477 US at 290.

44 Id at 289 (internal quotation marks omitted), quoting Baker v Carr, 369 US 186, 205 (1962).

45 The importance of sufficient advocacy was also noted in Warth, 422 US at 500-01, 515. See also text accompanying notes 26-30.

46 For a discussion of the relationship between sufficient advocacy and organizations with 
policing mechanism, which guarantees a modicum of fair representation. ${ }^{47}$ The principles of associational standing outlined in Brock have established the bedrock of interpretation for lower courts' application of the Hunt test.

\section{APPLICATION OF THE ASSOCIATIONAL STANDING DOCTRINE TO ORGANIZATIONS WITH INTERNAL CONFLICTS OF INTEREST}

Numerous courts have ruled on the standing of associations that litigated on behalf of some of their members even though other members of the organization opposed the litigation. In analyzing the standing of these potential parties, courts have consistently applied the three-part test articulated in Hunt. ${ }^{49}$ However, neither Hunt nor any of the subsequent Supreme Court cases discussed how the test should apply to organizations with internal conflicts of interest. ${ }^{30}$ Consequently, lower courts have struggled to apply the principles of Brock and the three prongs of the Hunt test. ${ }^{51}$

Although all three prongs of the Hunt test technically must be fulfilled in order to achieve associational standing, not all three are implicated by an organization seeking associational standing. Beyond finding that an organization does not have to have all of its members injured, courts have not focused on the first prong of the Hunt test when affirming or denying associational standing for organizations with internal conflicts of interest. ${ }^{53}$

Parts II.A and II.B will focus on the theoretical underpinnings and the lower courts' apparent divergent applications of the germaneness and individual participation prongs, respectively.

internal conflicts of interest, see Part III.B.

47 Brock, 477 US at 290 ("The very forces that cause individuals to band together in an association will thus provide some guarantee that the association will work to promote their interests."). This self-policing mechanism is typically enforced via the authorization procedures. See Part III.B.3.

48 See, for example, notes 66-79 and accompanying text.

49 Hunt, 432 US at 343 . See text accompanying note 8.

50 See note 9.

51 See note 10.

52 See Brock, 477 US at 284-85 (finding that association had standing because "many" members were injured).

53 See Charles Alan Wright, Arthur R. Miller, and Edward H. Cooper, 13 Federal Practice and Procedure $\$ 3531.9$ at 613-14 (West 2d ed 1984) (noting a lack of judicial concern regarding the first prong of the Hunt test - whether individual members can gain standing-in analyzing the cases of organizations with internal conflicts of interest). 
A. Lower Courts Differ in Applying the Germaneness Prong to Associations with Internal Conflicts of Interest

The second prong of the Hunt test requires that the organization seek to protect interests that are "germane to the organization's purpose." "In the ideal associational standing case, the association's litigation objectives would match both the strategy and goals of a single member litigating individually ${ }^{s s}$ and the stated goals and purpose of the organization's charter or constitution. Thus, when the litigation does not clearly relate to the stated purpose of the organization, such cases would be easily dismissed. ${ }^{57}$ However, it is unclear how closely the litigation and organization's purpose must align.

The Supreme Court has never clarified the limits to which the litigation must be "germane to the organization's purpose.,"ss Consequently, the lower courts disagree as to how central the litigation must be to the organization's purpose in order to grant organizational standing. This Comment will first establish a basic understanding of what is "germane to the organization's purpose," and then explore how lower courts have applied these standards to organizations with internal conflicts of interest.

1. The germaneness prong requires the subject of litigation to be pertinent to the organization.

Courts agree that the benefits of associational standing described in Brock ${ }^{39}$ will only be realized if the subject of the litigation is "central to the purpose" of the organization..$^{60}$ However, no courts have declared that the litigation itself must be the central purpose. Rather,

\section{Hunt, 432 US at 343.}

55 See NCAA v Califano, 622 F2d 1382, 1391 (10th Cir 1980) ("In the usual associational standing case, what the association wants to achieve in the lawsuit is unquestionably what its members want.").

56 Hunt, 432 US at 343.

57 Most of these types of cases never produce court decisions. For example, if the National Rifle Association pursued litigation attempting to overturn minority contracting laws in public schools, the court would dismiss it as outside the purpose of the organization.

58 See text accompanying notes 32-33.

59 Brock, 477 US at 288-90. See notes 36-48 and accompanying text.

60 See, for example, American Postal Workers Union v Frank, 968 F2d 1373, 1375 n 2 (1st Cir 1992) (implying that the "central to the purpose" test was appropriately used by the district court in denying standing); Peick v Pension Benefit Guarantee Corp, 724 F2d 1247, 1259-60 (7th Cir 1983) ("Associational standing is particularly appropriate when the association is seeking to represent interests which are central to the purpose of the organization."); Associated General Contractors of ND v Otter Tail Power Co, 611 F2d 684, 690-91 (8th Cir 1979) (holding that associational standing was lacking because there was no showing of how the interests at issue were "germane to the organization's purposes"). See also Wright, Miller, and Cooper, 13 Federal Practice and Procedure $\$ 3531.9$ at 614-17 (cited in note 53) ("Once the litigation ventures very far from the central concerns of the organization, the[ ] assumption [ ]" that the organization will represent the parallel interests of its members "simply cannot be indulged."). 
courts have provided lesser scrutiny examining the potential internal conflict of interest when the litigation is clearly within the central purpose of the organization.

The typical meaning of "germane" is "relevant or pertinent."," Most courts have focused on the latter definition and only require a standard of "pertinence" between the litigation's subject matter and the organization's purpose. ${ }^{63}$ This standard strikes a balance between providing many of the benefits discussed in Brock and setting a high enough bar to dissuade especially litigious organizations. Courts have found that " $[t] 00$ restrictive a reading of the [germaneness] requirement would undercut the interest of members who join an organization in order to effectuate 'an effective vehicle for vindicating interests that they share with others.", Consequently, the pertinence standard allows a court to set a baseline to prevent organizations from litigating and thereby "forcing the federal courts to resolve numerous issues as to which the organizations enjoy little expertise and about which few of their members demonstrably care." ${ }^{65}$

2. Lower courts are divided over the application of the germaneness prong.

Many courts have examined the second prong of the Hunt test in determining the appropriate limits of germaneness to an organization, but none has found that unanimity of membership is required, or that any internal conflict of interest automatically forecloses associational

61 See, for example, Pennell v City of San Jose, 485 US 1, 7 n 3 (1988) (finding germaneness prong fulfilled without thorough analysis because litigation fit squarely within the organization's stated purpose).

62 Black's Law Dictionary 695 (West 7th ed 1999).

63 See, for example, Retired Chicago Police Association v City of Chicago ("RCPA I"), 7 F3d 584, 607 (7th Cir 1993) (discussing the "pertinent" standard in determining whether an organization is representing the interests of members); Competitive Enterprise Institute $v$ National Highway Traffic Safety Administration, 901 F2d 107, 111-12 (DC Cir 1990) (stating that germaneness is satisfied by a "mere pertinence"); Humane Society of the United States $v$ Hodel, 840 F2d 45, 56 (DC Cir 1988) (holding that the germaneness prong "require[s] only that an organization's litigation goals be pertinent to its special expertise and the grounds that bring its membership together"); American Insurance Association v Selby, 624 F Supp 267, 271 (D DC 1985) ("An association's litigation interests must be truly unrelated to its organizational objectives before a court will declare that those interests are not germane."); Medical Association of the State of Ala $v$ Schweiker, 554 F Supp 955, 965 (M D Ala 1983) (holding that in order to fulfill the germaneness prong, the litigation must have a "reasonable connection with the reasons the members joined the organization and with the objectives of the organization"), affd, 714 F2d 107 (11th Cir 1983).

64 Hodel, $840 \mathrm{~F} 2 \mathrm{~d}$ at 56, quoting Brock, 477 US at 289-90. The Hodel court also recognized that too loose a reading would allow an organization with an incredibly diverse membership to challenge nearly any law and thus transform the organization into a "law firm seeking to sue in its own name." 840 F2d at 57-58. For further discussion of the "roving law firm" concept, see note 119.

65 Hodel, $840 \mathrm{~F} 2 \mathrm{~d}$ at 57. 
standing. ${ }^{66}$ Because federal courts have limited power to hear cases, ${ }^{67}$ courts have found that a lack of strong advocacy will prevent them from hearing cases. ${ }^{3}$ An internal conflict of interest may prevent an organization from being a zealous advocate because that organization may not fully pursue litigation when the interests of some of its members will be harmed by the litigation's success. ${ }^{69}$

In Sierra Club v Glickman, ${ }^{70}$ the Fifth Circuit articulated the most lenient standard. "The court granted the American Farm Bureau Federation standing to intervene on behalf of its members even though not all of its members supported intervention. ${ }^{n}$ The Fifth Circuit did not even require a majority of members to support the action, but found instead that an organization has "standing to sue if only a few members support it."

Other courts have found that "profound" conflicts of interest among the membership can prevent the litigation from being germane to the organization's purpose. In two cases entitled Retired Chicago Police Association v City of Chicago ("RCPA $I^{\text {" }}$ and " $R C P A I I$ "), the Seventh Circuit identified two types of situations in which the conflicts are so "profound" that they would automatically violate the sec-

66 See, for example, Sierra Club v Glickman, 82 F3d 106, 110 (5th Cir 1996) (granting the American Farm Bureau Federation representational standing to intervene as of right to protect the rights of farmers even though not all members supported the intervention); National Association of College Bookstores, Inc v Cambridge University Press, 990 F Supp 245, 251-52 (S D NY 1997) (granting standing while stating that "unanimity in organizations with thousands of members is rarely possible").

67 See US Const Art III, $\$ 2$, cl 1. See also Part I.A.

68 See, for example, Retired Chicago Police Association v City of Chicago, 76 F3d 856, 864 66 (7th Cir 1996) ("RCPA II") ("[T] he fact that the litigation, if successful, would harm some members' interests raises a concern that the association will not be fully committed to the litigation and, as a result, will not pursue the litigation with the zealous advocacy necessary to be an adequate representative.").

69 See, for example, id. See also NCAA v Califano, 622 F2d 1382, 1391-92 (10th Cir 1980) ("There is no 'case or controversy' here if unofficial contingents of the [organization] are seen cheering both sides of the litigation, while governing bodies of the institutions sit as spectators above the 'fight."); Mountain States Legal Foundation v Dole, 655 F Supp 1424, 1426 (D Utah 1987) ("Because associations typically consist of many members with potentially conflicting interests and views on any particular dispute, a danger exists that certain members of the association will be sympathetic to the adverse party. In such a case, there could be no legitimate controversy.").

70 82 F3d 106 (5th Cir 1996).

71 Id at 110 (allowing standing when only a few of the association's members supported the suit), citing Playboy Enterprises, Inc v Public Service Commission, 906 F2d 25, 34 (1st Cir 1990). Interestingly, Playboy does not support that proposition. Rather, Playboy, 906 F2d at 34, merely concludes that Hunt does not require an injury to more than one member. No analysis of the litigation's authorization occurs in Playboy.

72 Glickman, 82 F3d at 110 ("That all [] members support intervention is not dispositive.").

73 Id.

747 F3d 584 (7th Cir 1993).

7576 F3d 856 (7th Cir 1996). 
ond prong of the Hunt test. ${ }^{76}$ First, a profound conflict arises where an association seeks standing to directly sue some of its own members." Second, a profound conflict arises if the association did not properly authorize the suit, and the litigation, if successful, would cause a direct detriment to the interests of some of its members. ${ }^{78}$ The Seventh Circuit did not provide thorough explanations of why such profound conflicts violated Hunt's second prong, but simply stated that "[b]ecause the interests which [the organization] seeks to protect by maintaining this action do not reflect and are actually at odds with the interests of some of its members, they certainly cannot be said to be 'germane' to [the organization's] overriding purposes.",

In Polaroid Corp $v$ Disney, the Third Circuit held that similarly profound conflicts can prevent associational standing when a corporation seeks associational standing for its shareholders. ${ }^{81}$ In Polaroid, the court found management to be an "uncertain representative for the interests of the disadvantaged shareholders [in a tender offer], as it may have an eye to protecting the interests of the majority.", court concluded that because the management was unable to serve simultaneously as a vigorous advocate for the two opposing types of shareholders, the management should not be granted standing. In-

76 See $R C P A$ II, 76 F3d at $864 ; R C P A I, 7$ F3d at 606 . See also notes $77-78$ and accompanying text.

$77 R C P A$ I, 7 F3d at 606, discussing Southwest Suburban Board of Realtors, Inc v Beverly Area Planning Association, 830 F2d 1374, 1380-81 (7th Cir 1987) (denying standing because the association would be suing "certain of its members on behalf of others of its members").

$78 R C P A \quad I, 7$ F3d at 606, discussing Maryland Highways Contractors Association, Inc v Maryland, 933 F2d 1246 (4th Cir 1991) (denying standing because the suit would hurt minority members and because the association failed to observe its own bylaws). See also RCPA II, 76 F3d at 864-65 (noting that finding a direct, detrimental effect may mean that the litigation will not be germane to the association's purposes of helping its members, and that "the association will not be fully committed to the litigation and, as a result, will not pursue the litigation with the zealous advocacy necessary to be an adequate representative"). The Seventh Circuit identified a potential third conflict-suing the management of the association. However, this situation essentially is covered by the first scenario, in which an association sues one of its own members. See Builders Association of Greater Chicago v City of Chicago, 170 FRD 435, 439 n 3 (N D Ill 1996), discussing RCPA II, 76 F3d at 866.

79 RCPA II, 76 F3d at 863 . The court did note that authorization might aid in fulfilling the second prong. Id at 865 . See notes $117-120$ and accompanying text.

$80 \quad 862$ F2d 987 (3d Cir 1998).

81 Id at 999-1000 (denying the management standing as a representative of its shareholders in a tender offer due to concerns over the adequacy of representation).

82 Id. For further analysis of Polaroid, see P. Michelle Grigsby, Note, Does a Target Corporation Have Standing to Sue Under the All Holders Rule? The Third Circuit Says No in Polaroid Corp. v. Disney, 862 F.2d 987 (3d Cir. 1988), 58 U Cin L Rev 717 (1989).

83 Polaroid, 862 F2d at 999, citing Craig v Boren, 429 US 190, 194 (1976). and Singleton $v$ Wulff, 428 US 106, 114 (1976) (Blackmun) (plurality). But see Deborah K. Rush, Comment, The Third Circuit's Limitations on the Class of Plaintiffs Allowed to Assert Violations of the All Holders Rule: Polaroid Corp. v. Disney, 862 F.2d 987 (3d Cir. 1988), 68 Wash U L Q 415, 425-27 \& nn 91, 94 (1990) (criticizing the limitation on standing and suggesting that suits for breaches of fiduciary duty may be a more effective method for handling conflicts). 
deed, one basis for the constitutional requirement that a litigant have a personal stake in the litigation is "to assure that concrete adverseness which sharpens the presentation of issues." Comment will show that other courts have used the Seventh Circuit's profound conflicts test but have not formally recognized that categorization.

\section{B. When Members Must Intervene, Standing Is Denied under the Individual Participation Prong}

Organizations seeking associational standing must also fulfill Hunt's third prong: "neither the claim asserted nor the relief requested requires the participation of individual members in the lawsuit." ${ }^{\text {s5 }}$ The Supreme Court has found that the individual participation prong affects prudential rather than constitutional standing. ${ }^{85}$ However, courts have found that some internal conflicts of interest may reduce judicial efficiency because the organization cannot effectively assert a dissenting member's interests. ${ }^{87}$ This section will first establish a basic understanding of types of claims typically denied under the individual participation prong. Then it will explore how the lower courts have applied these standards to organizations with internal conflicts.

1. Courts deny associational standing when individualized proof is required.

Courts must examine both the "claim asserted" and the "relief requested" when applying the third prong of the Hunt test. ${ }^{8 s}$ In general, courts have denied associational standing in litigation that re-

84 Polaroid, 862 F2d at 999 (internal quotation marks omitted), quoting Simon $v$ Eastern Ky Welfare Rights Organization, 426 US 26, 38 n 16 (1976), in turn quoting Baker v Carr, 369 US 186, 204 (1962). Moreover, because the members of management may be individually harmed by the success of the tender offer, they may not act in the best interests of the shareholders, and thus would not be acting within the purpose of the organization. See Part III.B.4.

85 Hunt, 432 US at 343.

86 United Food and Commercial Workers Union Local 751 v Brown Group, Inc, 517 US 544,557 (1996) ("[T] The third prong of the associational standing test is best seen as focusing on these matters of administrative convenience and efficiency, not on elements of a case or controversy within the meaning of the Constitution."). Associational standing's original purpose was to allow more effective advocates than individual litigants. See text accompanying notes $42-44$. See, for example, Brock, 477 US 274, 275-76 (1986) ("[T]he doctrine of associational standing recognizes that the primary reason people join an organization is often to create an effective vehicle for vindicating interests that they share with others."); Patterson, 357 US at 459 ("The Association ... is but the medium through which its individual members seek to make more effective the expression of their own views.").

87 See, for example, National Association of College Bookstores, Inc v Cambridge University Press, 990 F Supp 245, 248-52 (S D NY 1997) (granting standing to the association although the suit would not be optimally efficient because of internal opposition).

88 Hunt, 432 US at 343 (phrasing the third prong of the test as, "neither the claim asserted nor the relief requested requires the participation of individual members in the lawsuit"). 
quires individual participation. ${ }^{89}$ Courts have typically denied associational standing when the remedy requested includes damages because individual participation is necessary in identifying the appropriate levels of individual damages. ${ }^{90}$ When an association requests damages, the damage claims are typically not shared by all members, and thus require individualized participation. ${ }^{91}$ In this situation, the advantages of associational standing are minimized: the organization is not the best representative of any member's individual interest because the organization is seeking to maximize the membership's total gain, perhaps necessitating sacrifices from individual members.

The Supreme Court has also uniformly denied standing to organizations when elements of the claim require the individual participation of members. For example, in religious expression cases, individuals normally must participate to show the coercive effect of a government action. ${ }^{32}$ In these types of claims, the advantages of judicial efficiency created by associational standing ${ }^{93}$ are reduced because individual members would be forced to participate individually to prove the elements of a claim.

89 See Wright, Miller, and Cooper, 13 Federal Practice and Procedure $\S 3531.9$ at n 144 (cited in note 53) (discussing cases applying individual participation prong).

90 See Telecommunications Research \& Action Center v Allnet Communication Services, Inc, 806 F2d 1093, 1094-95 (DC Cir 1986) ("[L]ower federal courts have consistently rejected association assertions of standing to seek monetary, as distinguished from injunctive or declaratory, relief on behalf of the organization's members.").

91 See, for example, Warth, 422 US at 490, 515-16 ("[W] hatever injury may have been suffered is peculiar to the individual member concerned and both the fact and extent of injury would require individualized proof"). However, this prohibition against monetary damages is of a prudential rather than a constitutional character, and thus may be allowed by statute or at a court's discretion. See United Food \& Commercial Workers Union Local 751 v Brown Group, Inc, 517 US 544, 554-58 (1996) (granting standing for union seeking back pay in employment suit).

92 For example, in religious freedom cases, one element of the cause of action, showing the coercive effect of government action, requires the individual participation of members. See Harris $v$ McRae, 448 US 297, 321 (1986). Granting an association standing in such a case would violate Hunt's third prong. Id (denying associational standing because free exercise violations require the showing of governmental action on an individual's free exercise claims); Board of Education of Central School District No 1 v Allen, 392 US 236, 248-49 (1968) (finding no free exercise violation because plaintiffs failed to allege that the statute in question had coerced them as individuals in the practice of their religion).

93 See Brock, 477 US at 288-90. See also text accompanying notes 38-47.

94 Associational standing has been denied under similar statutes requiring an individualized showing of impact. See, for example, Rent Stabilization Association of the City of New York $v$ Dinkins, 5 F3d 591, 596-97 (2d Cir 1993) (denying standing to association of landlords seeking only injunctive relief because city ordinance would require court to examine the details of each particular instance of poor administration); Kansas Health Care Association, Inc v Kansas Department of Social and Rehabilitation Services, 958 F2d 1018, 1022-23 (10th Cir 1992) (holding that an association of nursing facilities lacked standing because determining what is an "adequate" reimbursement rate would require the court to examine evidence particular to individual providers). 
2. Lower courts are in conflict over the application of the individual participation prong.

Various courts have applied Hunt's third prong to organizations with internal conflicts of interest but have come to seemingly contradictory results. Some circuits have found that conflicts of interest within an organization do not violate Hunt's third prong, but then courts grant associational standing under vastly different rationales. In contrast, two circuits held that an internal conflict of interest should prohibit associational standing because affected dissenting members will intervene to protect their individual interests.

Courts granting associational standing have relied on numerous rationales drawn from the Hunt analysis. The Ninth Circuit upheld an associational standing claim under the individual participation prong because the Supreme Court never inquired into whether the apple growers and dealers represented by the Washington State Apple Advertising Commission in Hunt unanimously agreed to the suit." Other courts have found that when a majority of the membership supports the litigation and the organization has followed its internal procedures, the internal conflict of interest does not prohibit associational standing, even if a minority of members may be adversely affected. For example, in Contractors Association of Eastern Pennsylvania, Inc $v$ City of Philadelphia, an association of construction contractors had standing to challenge the municipal ordinance that favored some of its

95 See Associated General Contractors of Cal, Inc v Coalition for Economic Equity, $950 \mathrm{~F} 2 \mathrm{~d}$ $1401,1408-09$ (9th Cir 1991) (granting associational standing without inquiring into unanimity of membership; arguing that Supreme Court did not inquire in Hunt and that as a policy matter it is not required); Contractors Association of Eastern Pa, Inc v City of Philadelphia, 945 F2d 1260, 1265-66 (3d Cir 1991) (granting associational standing in the face of conflicting interests because the association represented the interests of the majority of its members); National Maritime Union of America, AFL-CIO v Commander, Military Sealift Command, 824 F2d 1228, 1232-34 (DC Cir 1987) (arguing that the Court in Hunt had said that associational standing is too valuable of a tool to be abandoned because of conflicting interests and that the problem is best handled by the internal procedures of the organization).

96 See, for example, Maryland Highways Contractors Association, Inc v Maryland, 933 F2d 1246, 1252-53 (4th Cir 1991) (denying standing because the association's members had "actual conflicts of interest which would require that the individual members come into the lawsuit to protect their interests"); Associated General Contractors of ND v Otter Tail Power Co, 611 F2d 684, 691 (8th Cir 1979) (denying standing because actual and potential conflicts "require individual representation" of the association's members).

97 Associated General Contractors of Cal, 950 F2d at 1408-09, discussing Hunt, 432 US at 344 , and Brock, 477 US at $287-90$. Hunt, 432 US at 344, declared the third prong fulfilled because "neither the interstate commerce claim nor the request for declaratory and injunctive relief requires individualized proof and both are thus properly resolved in a group context." Similarly, in Brock, 477 US at 287-90, the Court did not inquire into the unanimity of membership nor the existence of internal conflicts of interest.

$98945 \mathrm{~F} 2 \mathrm{~d} 1260$ (3d Cir 1991). 
members over others because it had followed its own internal authorization procedures, thus ensuring the adequacy of representation."

Courts denying associational standing under the individual participation prong have found that some internal conflicts of interest are so large that affected dissenting members will intervene to protect their rights. ${ }^{100}$ Other circuits have found that even appropriate authorization is insufficient to overcome concerns regarding the individual participation prong. ${ }^{101}$ Consequently, the circuit courts' analyses apparently rely on numerous different rationales.

\section{PROPOSED SOLUTION}

Part II examined the apparent discord among the lower federal courts concerning the effect of an internal conflict of interest on an organization seeking associational standing. Part III will show that the seeming disorder can be easily understood by examining how courts have handled organizations with different intensities of internal conflicts of interest and internal authorization problems. Although courts have proposed numerous reasons for accepting or denying associational standing, ${ }^{102}$ an easily identifiable theme can be deduced from examining the totality of the case law: courts have universally granted standing to organizations that have minor internal conflicts, while generally increasing the level of scrutiny under either the germaneness prong or the individual participation prong when examining profound conflicts.

This Part proposes a test to formalize the underlying reasoning that lower courts have applied in examining organizations with internal conflicts of interest. In applying the Hunt test, courts should first determine what type of conflict exists. If the organization has a profound conflict, then the court must provide greater scrutiny both under the germaneness prong and under the individual participation prong. The court must then determine if the germaneness prong's concerns regarding sufficient constitutional adversity have been overcome by adequate authorization. The court must also examine if indi-

99 Id at $1265-66$.

100 See, for example, Maryland Highways Contractors, 933 F2d at 1252-53 ("[T]here are actual conflicts of interest which would require that the individual members come into the lawsuit to protect their interests.").

101 See, for example, Associated General Contractors of ND, 611 F2d at 691. The court noted:

The fact that the association voted unanimously to bring the lawsuit sheds little or no light on the germaneness of the lawsuit to the organization's purpose. It is for the court, not the members of the association, to determine whether their interests require individual representation. Here, in view of the actual and potential conflicts, they clearly do.

Id.

102 See Parts II.A.2 and II.B.2. 
vidual participation significantly impairs judicial efficiency or if alternative mechanisms exist to preserve the considerable benefits of associational standing.

To provide coherence to the lower courts' decisions, the underlying rationales behind both the germaneness prong ${ }^{103}$ and the individual participation prong ${ }^{104}$ must be analyzed and applied to organizations with internal conflicts of interest. Part III.B demonstrates how courts must examine how authorization affects constitutional adversity under the germaneness prong. Part III.C shows that identification of a profound conflict and its authorization can serve as a shorthand test to determine whether judicial efficiency will be impaired under the individual participation prong. Finally, Part III.D endorses alternative measures for courts to handle organizations with profound conflicts besides denying associational standing.

\section{A. Courts Must Assess Whether the Organization Has a Profound Internal Conflict of Interest}

In analyzing whether to grant associational standing, courts must first determine if the conflict is minor or profound. With a minor internal conflict of interest, members of the organization may dislike the litigation, but have no vested interest in its outcome. Courts have granted standing to organizations with these types of conflicts ${ }^{105}$ and should continue to do so. However, many conflicts have impacts on members that are more significant. The Seventh Circuit provides the best categorization of these types of conflicts by defining as profound conflicts those cases in which the organization is suing one of its own members or in which litigation will "cause a direct detriment" to some of the organization's members. ${ }^{106}$ Organizations with these types of conflicts are sometimes granted and sometimes denied associational standing. ${ }^{107}$

103 See Part II.A.1.

104 See Part II.B.1.

105 Most cases with minor internal conflicts of interest do not discuss them as relevant to the associational standing doctrine. However, a few have recognized that minor conflicts exist but are insignificant in the associational standing analysis. See, for example, Sierra Club v Glickman, 82 F3d 106, 110 (5th Cir 1996) (granting the American Farm Bureau Federation representational standing to intervene as of right to protect the rights of farmers even though not all members supported the intervention); National Association of College Bookstores, Inc v Cambridge University Press, 990 F Supp 245, 251 (S D NY 1997) ("[M]inor conflicts involving a small minority of an association's membership [are] immaterial to standing analysis."). 75-79.

$106 R C P A I I, 76$ F3d at 864, discussing RCPA I, 7 F3d at 606. See text accompanying notes

107 See, for example, Contractors Association of Eastern Pa $v$ City of Philadelphia, 945 F2d 1260,1266 (3d Cir 1991) (granting standing to construction association challenging constitutionality of minority set-aside ordinance because "there is nothing on this record indicating that [the association] failed to follow [its] own internal rules before joining this litigation"); National 


\section{B. Profound Conflicts Should Be Given Stricter Scrutiny under the Germaneness Prong}

After identifying a conflict as profound, the court should apply strict scrutiny to determine if the conflict will threaten the basis of the germaneness prong-the constitutional adversity of a case. Courts have never found that the existence of a profound conflict automatically prohibits standing. Rather, courts have claimed to examine numerous factors to determine the constitutional sufficiency of the claim. ${ }^{108}$ However, this Comment proposes formalizing the underlying analysis that courts have consistently used as a proxy to determine constitutional sufficiency: whether the litigation was properly authorized. ${ }^{109}$ The proposed test requires courts to apply the additional criterion of proper authorization when evaluating the germaneness prong ${ }^{110}$ because of the potential for a bare majority or influential minorities to commandeer the litigation process."

\section{Profound conflicts can threaten constitutional adversity.}

An organization with a profound internal conflict may yield to pressures from dissenting members and alter its litigation strategy. The conflict could disrupt the organization and diminish the zealousness

Maritime Union of America, AFL-CIO v Commander, Military Sealift Command, 824 F2d 1228 , 1232-34 (DC Cir 1987) (denying standing to union representing both workers who would be helped by a successful challenge of award of government contract and workers who would be injured by a successful challenge).

108 See Part II.A.2.

109 Although no definition of "proper authorization" has been formally adopted, each court seems to undertake a particularized analysis focusing on numerous issues, such as: (1) authorization according to the organization's own procedures (see, for example, $R C P A I I, 76 \mathrm{~F} 3 \mathrm{~d}$ at 865 (identifying the importance of procedures in assuring membership approval) and Contractors Association of Eastern $\mathrm{Pa}, 945 \mathrm{~F} 2 \mathrm{~d}$ at $1265-66$ (granting standing in part because "there is nothing on this record indicating that [the association] failed to follow [its] own internal rules before joining this litigation")); (2) notifying the membership of the litigation (see, for example, Maryland Highways Contractors Association, Inc v Maryland, 933 F2d 1246, 1253 (4th Cir 1991) (noting in denying standing that "the Board took the unusual position of not telling the members of its decision to litigate until after the suit had already been filed")); (3) receiving the endorsement of the membership (see, for example, Associated General Contractors of Cal, Inc $v$ Coalition for Economic Equity, 950 F2d 1401, 1409 (9th Cir 1991) (urging that associational standing be granted whenever the litigation has the "clear mandate of the association represented")).

110 The party seeking associational standing should bear the burden of showing that the procedure was properly authorized. See $R C P A I I, 76$ F3d at 865 . An organization bears the burden of proving that it meets the required elements of standing. Lujan $v$ Defenders of Wildlife, 504 US 555, 561 (1992). These elements include following the appropriate authorization procedures.

111 A court must examine conflicted organizations with greater scrutiny because of the concern that they will be less zealous and thus inadequately represent their members' interests. See Brock, 477 US at 289 ("[T]he litigation strategy selected by the association might reflect the views of only a bare majority-or even an influential minority-of the full membership."); Simone, Note, 61 BU L Rev at 179-81 (cited in note 40) (discussing possibilities of inadequate representation when associations seek standing). 
with which the organization pursues the litigation, ${ }^{112}$ perhaps even to the point of failing the constitutional threshold of case or controversy. ${ }^{113}$ Consequently, a court could find that an organization is not the most effective advocate, and that litigation may be pursued more effectively on an individual level. ${ }^{114}$

2. Authorization can cure the constitutional adversity problems inherent even in organizations without internal conflicts of interest.

Appropriate authorization of the litigation may have a significant impact on a court's decision to grant standing to any organization seeking to represent the interests of its members. Courts have denied standing to organizations-even to those without any internal conflicts of interest-if they failed to follow authorization or notification procedures. ${ }^{115}$ Consequently, courts have extensively examined the impact of adequate authorization on the germaneness and individual participation prongs for organizations with internal conflicts of interest. Legitimate authorization will ensure the membership's support of the litigation, and thus vitiate any constitutional concerns encountered in applying the germaneness prong.

3. Authorization can help ensure constitutional adversity by increasing the zealousness of advocacy.

Although courts have espoused many reasons for approving or disapproving associational standing, their analyses under the germaneness prong often turn on the effects of authorization on constitutional adversity. ${ }^{116}$ Authorization ensures that the litigation as a whole

112 See RCPA II, 76 F3d at 865.

113 See text accompanying notes 15-22.

114 The problem of zealous advocacy may be diminished by appropriate authorization. See $R C P A I I, 76$ F3d at 865 . See also Part III.B.3.

115 See, for example, Local 194, Retail, Wholesale and Department Store Union $v$ Standard Brands, Inc, 540 F2d 864, 867-68 (7th Cir 1976) (suggesting that a provision should be added for notice to individual members so that those who choose not to be represented by the union may make other arrangements); Natural Resources Defense Council, Inc v EPA, 507 F2d 905, 908-11 \& $n 6$ (9th Cir 1974) (denying standing to the NRDC because the litigation was not approved by or authorized by affected members).

116 Only one court has incorrectly reasoned that courts should independently determine whether they have the authority to hear the case. See Associated General Contractors of ND v Otter Tail Power Co,611 F2d 684, 691 (8th Cir 1979) (finding that the unanimous approval of the litigation by members "sheds little or no light on the germaneness of the lawsuit to the organization's purpose"). Most courts disagree with the Eighth Circuit and find that authorization aids in assuring zealous advocacy to meet the constitutional requirement of case or controversy. See, for example, RPCA II, 76 F3d at 865 (explaining that whenever litigation is "authorized in accordance with the association's procedures ... the membership has affirmed that the detriment to some members' interests does not render the litigation outside the germane interests of [the] as- 
falls within the scope of legitimate association action because proper authorization indicates the membership's collective will to support the litigation. With authorization, the membership has affirmed that the detriment to some members' interests does not render the litigation outside the interests of the association. ${ }^{117}$ Such circumstances should assure courts that the association will pursue the litigation with the strong advocacy and persistence necessary to be an effective representative. ${ }^{118}$ Consequently, an organization approving the litigation through the proper authorization procedures would fulfill the germaneness prong. ${ }^{119}$ Since most litigation is properly approved, most organizations with internal conflicts of interest would satisfy the germaneness prong and would be able to gain standing. ${ }^{120}$

sociation, assur[ing] that [it] will pursue the litigation with the strong advocacy and persistence necessary to be an effective representative."). Simply assuring that the litigation was authorized does not solve all possible concerns a court may encounter when applying the Hunt test. For example, a profound conflict problem could still create problems under the individual participation prong. See Part III.B.4.

$117 R C P A \quad I I, 76 \mathrm{~F} 3 \mathrm{~d}$ at 865 . See note 116.

118 See Builders Association of Greater Chicago v City of Chicago, 170 FRD 435, 439 (N D Ill 1996) ("When the litigation has been properly authorized, there is less concern that the rights of dissenting members will be compromised or that the association will not provide the 'zealous advocacy necessary to be an adequate representative."'), quoting $R C P A I I, 76 \mathrm{~F} 3 \mathrm{~d}$ at 865 .

119 See, for example, Contractors Association of Eastern Pa v City of Philadelphia, $945 \mathrm{~F} 2 \mathrm{~d}$ 1260, 1265-66 (3d Cir 1991) (granting standing in part because "there is nothing on this record indicating that [the association] failed to follow [its] own internal rules before joining this litigation"); Associated General Contractors of Conn, Inc v City of New Haven, 130 FRD 4, 10 (D Conn 1990) ("Unanimity among AGC's members is not a requirement for its standing. Resolution of frictions within AGC's membership is a matter of its governance. As long as the suit is not in contravention of its purposes nor its by-laws which govern its decision making process, it has standing."). Some concerns remain about an organization that attempts to become a "roving law firm with standing" for any particular-interest case. This organization could structure itself so that it could easily alter its constitution to meet the pertinence standard for each case it brings without strong support for the litigation from the membership. However, in such circumstances, Hunt's first prong still requires an organization seeking standing to meet the Lujan requirements of particularized injury. See Lujan v Defenders of Wildlife, 504 US 555, 560-61 (1992); Humane Society of the United States v Hodel, 840 F2d 45, 56 n 16 (DC Cir 1988) ("[T]he independent first prong of the Hunt test ... would of course provide a significant check on renegade leaders of litigious associations."). See also note 17. If the organization is large enough to encompass many individuals so that a single member is likely to have an injury for any given litigation (for example, a national political party with tens of millions of members), the organization will likely also have a member who would be on the opposite side of the litigation. Thus, associational standing would be denied under the individual participation prong. Moreover, courts have not expressed serious concern over granting associational standing to organizations created specifically for the purpose of litigation. See, for example, Pennell v City of San Jose, 485 US 1, 7 n 3 (1988) (finding the germaneness prong fulfilled because the association claimed to be "'organized for the purpose of representing the interests of the owners and lessors of real property' in San Jose in this lawsuit") (citation omitted).

120 Conflicts should be examined under the individual participation prong. See Part III.C. Some litigation may be properly approved but still fail the mere pertinence standard of the germaneness prong. See note 62 . 
4. Some conflicts may cause an association to fail the requirement of constitutional adversity even when the litigation is properly authorized.

Proper authorization will not necessarily solve all of the constitutional concerns regarding a court's jurisdiction. In some situations, those who control the approval and direction of the litigation may have an individual stake in the litigation (besides their representative capacity) that could directly conflict with the interests of the rest of the membership. ${ }^{121}$ In these types of situations, even if the litigation has been appropriately approved, the court should deny standing because of the potential for inadequate representation. However, these situations occur quite infrequently and only when the authorization and representation functions are merged. ${ }^{12}$

Proper authorization provides numerous benefits in ensuring that an association meets the constitutional requirements for standing. Because profound conflicts can undermine the adversity required to meet the Article III case-or-controversy requirement, proper authorization can ensure that the organization as a whole supports the litigation and thus will zealously pursue the litigation. However, a few organizations, ones whose representative and authorization functions are merged, will be incapable of zealously advocating for minority interests, and thus should be barred from gaining associational standing.

\section{Conflicts of Interest Should Be Examined under the Individual Participation Prong}

The proposed test also requires heightened scrutiny under the individual participation prong whenever a profound conflict exists. Internal conflicts of interest may require individuals to intervene to protect their interests, thus violating the third prong of the Hunt test. ${ }^{123}$ This Comment proposes adopting the profound conflicts test ${ }^{124}$ as an initial screening device to identify situations in which dissenting members are likely to intervene to protect their rights: when the organiza-

121 These situations occur in cases in which the management's future livelihood directly conflicts with the financial interests of the membership. See, for example, Polaroid, 862 F2d at 999-1000 ("While shareholders ... have a reason to react favorably to many tender offers, those in control of the target corporation have a natural incentive to resist a corporate takeover [because they] may suffer a substantial loss in future earnings if the tender offer is successful."). For further discussion of Polaroid, see text accompanying notes 81-84.

122 This situation occurred only once in the more than forty cases examined-in Polaroid. See note 121 . The presence of such a conflict may have resulted from the unusual entity that sought associational standing (a corporation). Typical plaintiffs, business associations or unions, usually do not possess these unique types of conflicted interests.

123 See Hunt, 432 US at 343 ("[N]either the claim asserted nor the relief requested requires the participation of individual members in the lawsuit.") (emphasis added).

124 See text accompanying notes 74-78. 
tion is suing one of its own members and when success of the litigation will cause a direct detriment to a member. Thus, the profound conflicts test, originally used in RCPA II to examine constitutional adversity, ${ }^{125}$ effectively identifies areas that may require individual participation, and thus would require heightened scrutiny.

1. The profound conflicts test should identify situations in which members will intervene to protect their interests.

Associational standing provides tremendous benefits not only for an organization's members, ${ }^{126}$ but also for the judiciary. ${ }^{12}$ Indeed, Hunt's third prong appears primarily concerned with increasing judicial efficiency. ${ }^{128}$ Under the individual participation prong, the profound conflicts test serves as a shortcut in determining when individual members will be required to intervene to protect their interests. This shortcut ensures one of the primary purposes of associational standing identified in Brock: an efficient adjudication of common claims without the formalities of a class action proceeding. ${ }^{129}$ The Supreme Court observed in Brock that "the doctrine of associational standing recognizes that the primary reason people join an organization is often to create an effective vehicle for vindicating interests that they share with others." ${ }^{\text {130 }}$ Individuals become members of organizations and contribute financial resources, political support, or time for the express purpose of furthering a common goal. ${ }^{131}$ The proposed test would require courts to examine closely whether the two types of profound conflicts require the individual participation of dissenting members.

Many "direct detriment" conflicts will require individual participation. In some situations, successful litigation will result in the loss of statutory benefits for dissenting members ${ }^{132}-$ when the statute is over-

125 See $R C P A I I, 76$ F3d at 863-66.

126 These benefits include the organization's greater resources and expertise in the subject matter as well as the organization's role in overcoming the collective action problem of its members. See Brock, 477 US at 288-90. See also text accompanying notes 38-43.

127 See Brock, 477 US at 288-90. See also text accompanying notes 38-43.

128 See United Food and Commercial Workers Union Local 751 v Brown Group, Inc, 517 US 544,557 (1996) ("[T]he third prong of the associational standing test is best seen as focusing on these matters of administrative convenience and efficiency, not on elements of a case or controversy within the meaning of the Constitution."). See also text accompanying note 35.

129 See 477 US at 288-90. See also Part I.B.

130477 US at 290.

131 See Joint Anti-Fascist Refugee Committee v McGrath, 341 US 123, 187 (1951) (Jackson dissenting) ("[P]eople pool their capital, their interests, or their activities under a name and form that will identify collective interests.").

132 See, for example, Maryland Highways Contractors Association, Inc v Maryland, $933 \mathrm{~F} 2 \mathrm{~d}$ 1246, 1252-53 (4th Cir 1991) (denying standing to an association of contractors challenging a minority business enterprise statute because some of its members would benefit from the contin- 
turned these individuals are effectively denied any potential recourse. Theoretically, individual members could attempt to pressure the legislature to enact similar benefits. However, the likelihood of success of such an effort is effectively zero. Members who currently benefit from the statute consequently must present their legal arguments during the litigation through intervention or lose any chance of preserving their benefits.

In other direct detriment cases, successful litigation will not automatically deny any form of relief to dissenting members, but instead will force such members to litigate on their own behalf. ${ }^{13}$ However, these dissenting members will face additional burdens resulting from the association's actions: 1 ) some courts may find that the dissenting member and the organization share such a unity of facts and interest that the litigant would be precluded from a collateral attack upon the judgment; ${ }^{134}$ or 2 ) individuals may be hampered by the stare decisis effect of the litigation..$^{135}$ Thus, many direct-detriment conflicts would seem to result in a denial of associational standing because heightened scrutiny under the individual participation prong will show that individual members must participate in order for their interests to be adequately represented. However, courts can and should find alternate methods to preserve dissenting members' interests while still granting standing to the organization. ${ }^{136}$

The other profound conflict-the "suing one's own" conflict" also automatically requires individual participation. A member who is sued is a necessary party to the litigation ${ }^{135}$ and must participate in or-

ued enforcement of the statute while others would benefit if the law were declared unconstitutional).

133 See, for example, National Maritime Union of America, AFL-CIO v Commander, Military Sealift Command, 824 F2d 1228, 1233-34 (DC Cir 1987) (holding that unions representing employees of unsuccessful bidders for government contracts need not be denied standing to challenge award of contract simply because individual dissenting members may decide to intervene).

134 Courts will apply the doctrine of res judicata and preclude a subsequent claim when: (1) the first judgment was final and on the merits; (2) the prior action involved the same parties or their privies; and (3) the prior action involved essentially the same claim. James Wm. Moore, 18 Moore's Federal Practice $\$ 131.01$ at 131-11 to 131-12 (Matthew Bender 3d ed 2001).

135 A court will not automatically preclude a dissenting member from relitigating because there may not be a unity of facts and interests. However, the stare decisis effect will likely insulate the defendant from future collateral attacks. Although a previous ruling will not bind a dissenting member, the precedential effect provides an additional hurdle for an individual member seeking to validate a claim. See Chicago-Midwest Meat Association v City of Evanston, 589 F2d 278, 280-81 \& n 3 (7th Cir 1978) ("The stare decisis effect of our decision provides the defendants with substantial protection against further litigation.").

136 See Part III.D.

137 The first category of profound conflict is identified in $R C P A I I, 76 \mathrm{~F} 3 \mathrm{~d}$ at 864 . See also note 124.

138 See FRCP 19 (discussing further ideas regarding necessary and indispensable parties, without whom a suit may not proceed). 
der to protect her own rights and respond to any claims brought against her. Consequently, courts should deny associational standing to any organization that is suing one of its own members. ${ }^{139}$

Minor conflicts outside these two categories will not be a bar under this proposed solution. Because only profound conflicts receive heightened scrutiny, organizations with conflicts that do not reach that level will be granted associational standing. Regardless of the judicial theory supposedly relied upon, courts have consistently granted associational standing for organizations that have minor conflicts falling outside the two types of profound conflicts. ${ }^{140}$ Minor conflicts should not prevent associational standing because granting such power to "remote interests of discrete members would seriously undermine the ability of individuals through organizations to achieve public interest objectives through the legal system."

2. Courts should examine the litigation's authorization process in order to aid judicial efficiency.

The proposed solution recognizes that an organization cannot be a single monolithic entity with complete unanimity of interests. All associations will have some conflicts, ${ }^{142}$ especially since most are formed around broad purposes. ${ }^{1.3}$ As a result, "because internal conflicts are endemic to associations, members expect to incur certain costs to their own interests upon joining." ${ }^{144}$ Members are willing to sacrifice a por-

139 This doctrine can be extended to similar situations, such as when an organization sues its own management. See, for example, RCPA II, 73 F3d at 866 (noting that the suing-one's-own conflict arose when the RCPA claimed that one of its own officers breached his fiduciary duty).

140 See, for example, Gillis $v$ United States Department of Health and Human Services, 759 F2d 565, 572-73 (6th $\mathrm{Cir}$ 1985) (granting an association standing to challenge a hospital's failure to fulfill statutory obligations because the negative impact of successful litigation on association members was "both speculative and indirect"). See also National Constructors Association v National Electrical Contractors Association, Inc, 498 F Supp 510, 521-22 (D Md 1980) (approving associational standing, although the organization had a diversity of interests, because the litigation was not "work[ing] against [any] member's interest").

141 Gillis, 759 F2d at 572-73.

142 See, for example, National Association of College Bookstores, Inc v Cambridge University Press, 990 F Supp 245, 251-52 (S D NY 1997) ("[U]nanimity in organizations with thousands of members is rarely possible.").

143 See Associated General Contractors of Cal, Inc v Coalition for Economic Equity, 950 F2d 1401, 1409 (9th Cir 1991) ("Unanimous opinions within an organization's membership will be few and far between with regard to most issues controversial enough to engender litigation.").

144 National Maritime Union of America, AFL-CIO v Commander, Military Sealift Command, 824 F2d 1228, 1233-34 (DC Cir 1987). The case states:

Most, or perhaps all, associations, even though created to serve the members' common interests, will have internal conflicts about appropriate organizational policies. Such conflicts are typically resolved by the association's internal procedures or political structure. Inevitably, some resolutions will harm some members' interests, but that is usually accepted as part of the cost of obtaining the benefits of association. Courts would ordinarily uphold an association's determinations against internal challenge unless it were shown that the organiza- 
tion of their individual interests to achieve a greater common objective. Consequently, this Comment recommends taking advantage of the self-policing mechanism identified in Brock that helps to assure that organizations only pursue actions favorable to the entire organization. ${ }^{145}$ This process, exemplified by appropriate authorization, ${ }^{46}$ ensures that the organization has evaluated the litigation and determined that pursuing the litigation will further the organization's goals, even if individual members will be injured. ${ }^{147}$

Courts should grant standing to an organization only when the organization has properly approved the litigation. Otherwise, individuals would be unable to "create an effective vehicle for vindicating interests that they share with others. ${ }^{\text {, }}{ }^{\text {t4 }}$ All of the interested members would be forced to litigate the problem individually, requiring the courts to hear multiple cases and thus drastically reducing judicial efficiency. ${ }^{199}$ Given the Supreme Court's espoused preference for associational standing and its importance as a mechanism for litigating individual members' claims, ${ }^{150}$ courts should not lightly deny associational standing even when there is a profound conflict that requires individual participation.

tion's own procedures had been violated. It is not obvious to us that this rationale should not apply to an association's internal resolution of conflicts about litigating positions. Id.

145 See Brock, 477 US at 290 ("The very forces that cause individuals to band together in an association will thus provide some guarantee that the association will work to promote their interests.").

146 See Part III.B.

147 See Humane Society of the United States v Hodel, 840 F2d 45, 56 (DC Cir 1988), quoting Brock, 477 US at 290:

The third "special feature" of associations cited in [Brock], their self-policing character, would seem to carry particular force on the germaneness issue. If the "forces that cause individuals to band together" guarantee some degree of fair representation, they surely guarantee as well that associational policymakers will not run roughshod over the strongly held views of association members in fashioning litigation goals.

Obviously some concern exists regarding influential minorities commandeering the approval process. However, these concerns can be allayed via traditional organizational remedies, such as actions for breach of fiduciary duty or violation of an organization's charter. See text accompanying note 158.

148 Brock, 477 US at 290.

149 See National Association of College Bookstores, 990 F Supp at 248-52 (stating that denying representational standing to an organization with an internal conflict of interest "would clearly be inimical to the goals of judicial efficiency: It is precisely in cases where large organizations are present that the greatest benefits are to be reaped by collective adjudication.").

150 See Brock, 477 US at 288-90 (discussing the strengths of associational standing and its importance for the just adjudication of claims). See also text accompanying notes 38-47. 


\section{Courts Should Preserve Dissenting Members' Rights through Less Drastic Measures than Denial of Standing}

The proposed test requires heightened scrutiny to determine when profound conflicts diminish constitutional adversity or reduce judicial efficiency under Hunt's second and third prongs, but it also requires courts to dismiss standing claims only in extreme circumstances. In light of the tremendous benefits derived from associational standing, ${ }^{\text {'S1 }}$ courts should explore whatever means possible to allow associational standing.

However, in some situations, a court may find that the unique combination of circumstances makes alternative mechanisms unworkable and that a party is "indispensable" to the litigation. ${ }^{133}$ The court should deny associational standing to the organization in such a case because the dissenting member is "required" to participate in the litigation, thus violating Hunt's third prong. ${ }^{154}$ Eventually, the suit could be filed again, but interested individuals who bring the suit would lack the expertise and resources of the original organization."

Before dismissal, courts should examine any alternative mechanisms of preserving dissenting members' rights. The proposed test incorporates the methods by which numerous courts have taken into account dissenters' interests:

1) by liberally approving of dissenting members' intervention in the lawsuit to a) protect their rights or $b$ ) show that authorization procedures were violated and that associational standing should therefore be denied $;^{156}$

2) by allowing subsequent claims by dissenting members; ${ }^{157}$ or

151 See Brock, 477 US at 288-90. See also text accompanying notes 38-47.

152 See, for example, Builders Association of Greater Chicago v City of Chicago, 170 FRD 435, 438-39 (N D Ill 1996) (noting "'less drastic ways' to protect the rights of dissenting members of an association than denying associational standing"), quoting Brock, 477 US at 290.

153 See James Wm. Moore, 4 Moore's Federal Practice $\$ \S 19.03-19.06$ at 19-33 to 19-114 (Matthew Bender 3d ed 2001) (discussing the contours of "indispensable" parties under FRCP 19 and recommending "fact-specific" determination of parties necessary to litigation).

154 See Hunt, 432 US at 343. See also text accompanying note 8. For discussion of such examples, see Part III.C.1.

155 See Brock, 477 US at 288-90. See also text accompanying notes $42-43$.

156 See, for example, Associated General Contractors of California, Inc v Coalition for Economic Equity, 950 F2d 1401, 1408-09 (9th Cir 1991) (holding that dissenters' interests "should be taken into account ... through liberal approval of intervention"); National Maritime Union of America, AFL-CIO v Commander, Military Sealift Command, 824 F2d 1228, 1233-34 (DC Cir 1987) (suggesting that individual members "could intervene to advance their interests [or] challenge the association's standing").

157 See, for example, Associated General Contractors of Cal, 950 F2d at 1408-09 ("[T]he interests of [ ] dissenters should be taken into account ... through refusal to preclude subsequent claims by dissenting members."); National Maritime Union, 824 F2d at 1233 n 9 ("Members adversely affected by an association's litigation victory might be able to relitigate the claim on 
3) by allowing subsequent actions seeking compensation for misbehavior of the organization. ${ }^{158}$

Each of these remedies would allow individual dissenting members to protect their interests but would not require the dismissal of what the Supreme Court has described as "the special features [of associational standing], advantageous both to the individuals represented and to the judicial system as a whole."

\section{CONCLUSION}

Associational standing enhances judicial efficiency and helps secure the just administration of members' rights. However, the internal conflicts of an organization initially appear to violate several prongs of the Supreme Court's test to ensure constitutional standing and effective representation. The confusing lower court analyses can be clarified by a multi-part test examining the authorization process of profound conflicts to determine if sufficient constitutional adversity exists. A court should only dismiss based on a lack of associational standing when a conflict is so profound that it requires dissenting members to intervene to protect their rights-either because they are being sued or because the litigation will cause a direct detriment to their interests. Even then, courts will best fulfill the Court's desired efficient advocacy by seeking to preserve the rights of dissenting members through other avenues. In summary, courts must consider the tremendous benefits of associational standing and seek alternative mechanisms to preserve this valuable tool for both an organization's members and the courts.

which the association prevailed without operation of preclusion principles, i.e., res judicata or collateral estoppel."); Associated General Contractors of Conn, Inc v City of New Haven, 130 FRD 4, 10 (D Conn 1990) ("[A] judgment won against an association might not preclude subsequent claims by members where an association is deficient in representation."), citing Brock, 477 US at 290. Some commentators suggest that preclusion is not a viable solution to problems of adequate representation. See, for example, Simone, Note, $61 \mathrm{BU}$ L Rev at 185-87 (cited in note 40) (noting that courts seldom use an adequate scrutiny standard when precluding subsequent litigation). However, a court will not automatically preclude a dissenting member from initiating a future claim because there may not be a unity of facts and interests. See note 134 and accompanying text. Rather, stare decisis will probably insulate the defendant from future collateral attacks but will not bind a dissenting member who has a strong case to overturn the judgment. See Chicago-Midwest Meat Association $v$ City of Evanston, 589 F2d 278, 280-81 \& n 3 (7th Cir 1978). See also note 135.

158 See, for example, National Maritime Union, 824 F2d at 1233 n 9 (discussing possible "cause[s] of action arising therefrom for breach of fiduciary duty or of the organization's by-laws, charter or governing statutes against those who initiated the suit").

159 Brock, 477 US at 289. 


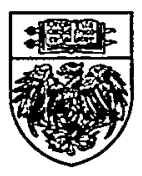

